\title{
The Influence of Promotion and Service Quality on Insurance Policy Purchase Decisions at PT. Tugu Kresna Pratama Bengkulu City
}

\section{Pengaruh Promosi dan Kualitas Pelayanan Terhadap Keputusan Pembelian Polis Asuransi pada PT. Tugu Kresna Pratama Kota Bengkulu}

\author{
Meliyus Astutiana1); Ermy Wijaya2); Andriyani Prawitasari2) \\ 1)Study Program of Management, Faculty of Economic, Universitas Dehasen Bengkulu \\ ${ }^{2)}$ Department of Management, Faculty of Economic, Universitas Dehasen Bengkulu \\ Email: 1)meliyus25@gmail.com
}

\section{How to Cite :}

Astutiana, M., Wijaya, E., Prawitasari. (2021). The Influence of Promotion and Service Quality on Insurance Policy Purchase Decisions at PT. Tugu Kresna Pratama Bengkulu City. EMAK: Jurnal Ekonomi Manajemen Akuntansi Dan Keuangan, 2(4). DOI: https://doi.org/10.53697/emak.v2i3

ARTICLE HISTORY

Received [12 Agust 2021]

Revised [25 Agust 2021]

Accepted [05 October 2021]

KEYWORDS

Promotion, Service Quality,

Purchasing Decisions.

This is an open access article under the $C C-B Y$-SA license

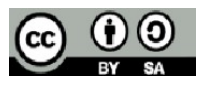

\section{ABSTRAK}

Tujuan penelitian ini adalah Promosi dan Kualitas Pelayanan terhadap Keputusan Pembelian Polis Asuransi pada PT. Tugu Kresna Pratama Kota Bengkulu. Metode analisis yang digunakan adalah Uji validitas, Uji Reliabilitas, Regresi Linear Sederhana, Koefisien Determinasi, Uji F dan Uji t. Hasil penelitian menunjukkan bahwa Promosi (X1) secara parsial berpengaruh signifikan terhadap keputusan pembelian polis asuransi pada pada PT. Tugu Kresna Pratama Kota Bengkulu (Y) karena nilai signifikannya $0,046<0,05$. Kualitas pelayanan (X2) secara parsial berpengaruh signifikan terhadap keputusan pembelian polis asuransi pada pada PT. Tugu Kresna Pratama Kota Bengkulu (Y) karena nilai signifikannya $0,000<0,05$. Variabel promosi $(X 1)$, kualitas pelayanan (X2) secara simultan atau bersama-sama berpengaruh signifikan terhadap keputusan pembelian polis asuransi pada pada PT. Tugu Kresna Pratama Kota Bengkulu karena nilai signifikannya 0,000 0,05.

\section{ABSTRACT}

The purpose of this study is the promotion and quality of service to the decision to purchase an insurance policy at PT. The Krishna Pratama Monument in Bengkulu City. The analytical method used is the validity test, reliability test, Multiple linear regression, coefficient of determination, $F$ test and $t$ test. Based on the research results indicate that Promotion (X1) partially has a significant effect on the purchase decision of an insurance policy at PT. Tugu Kresna Pratama Bengkulu City $(Y)$ because the significant value is $0.046<0.05$. Service quality (X2) partially has a significant effect on the purchase decision of an insurance policy at PT. Tugu Kresna Pratama Bengkulu City $(Y)$ because the significant value is $0.000<0.05$. Promotion variable (X1), service quality (X2) simultaneously or together have a significant effect on the purchase decision of an insurance policy at PT. Tugu Kresna Pratama Bengkulu City because the significant value is $0.000<0.05$.

\section{PENDAHULUAN}

Pada dasarnya manusia memiliki kehidupan yang kompleks dan tidak dapat diprediksi apa yang akan terjadi di masa mendatang, sehingga manusia harus mencari cara untuk meminimalisir resiko yang akan dihadapi di masa mendatang. Risiko dalam kehidupan yang dihadapi manusia 
tidak bisa dihilangkan, hanya bisa diminimalkan. Risiko kehidupan baik dari sisi kesehatan maupun jiwa semuanya mengarah pada satu ancaman yaitu mengurangi atau bahkan menghilangkan kemampuan finansial seseorang. Cara untuk meminimalisir resiko tersebut kerugian, kerusakan maupun kehilangan keuntungan yang diharapkan salah satunya adalah dengan memiliki polis asuransi.

Salah satu perusahaan asuransi yang menawarkan polis asuransi penjaminan kontrak (surety bond) adalah PT. Tugu Kresna Pratama Kota Bengkulu. Penjaminan kontrak (surety bond) ini merupakan suatu bentuk penjaminan dimana pihak obligee (pemilik pekerjaan/proyek) meminta Surat Jaminan dari Principal (kontraktor/pemborong) dengan maksud untuk menyatakan kesungguhan Principal dalam melaksanakan pekerjaannya sesuai kontrak/perjanjian yang telah disepakati.

Semua produk asuransi mempunyai manfaat dalam kehidupan yaitu dapat mengalihkan risiko finansial baik sebagian maupun seluruhnya kepada perusahaan asuransi yang diakibatkan oleh kejadian yang tak terduga serta sebagai investasi dan tabungan. Akan tetapi yang menjadi kendala dalam pemasaran polis asuransi saat ini adalah kurangnya minat nasabah untuk membeli polis pada PT. Tugu Kresna Pratama Bengkulu dikarenakan banyaknya pesaing dalam usaha sejenis dari perusahaan asuransi yang sudah lama dan terkenal di Bengkulu, serta adanya wabah pandemi virus covid 19 yang melanda dunia termasuk Indonesia tak terkecuali juga Bengkulu terkena dampaknya dimana pekerjaan pembangunan proyek-proyek pemerintah maupun swasta seperti gedung perkantoran, sekolah, perumahan, jalan dan lain-lain juga tidak bisa berjalan seperti biasanya, karena dana pembangunan banyak dialihkan oleh pemerintah untuk mengatasi wabah covid 19.

Meskipun usaha promosi dan kualitas pelayanan menjadi perhatian dan telah dilakukan PT. Tugu Kresna Pratama Kota Bengkulu akan tetapi saat ini minat nasabah untuk membeli polis asuransi penjaminan (surety bond) tidak mengalami peningkatan dikarenakan banyaknya pesaing dalam usaha sejenis dari perusahaan asuransi yang sudah lama dan terkenal di Bengkulu, serta adanya wabah pandemi virus covid 19 yang menyebabkan pekerjaan pembangunan proyek-proyek pemerintah banyak dialihkan oleh pemerintah untuk mengatasi wabah covid 19.

\section{LANDASAN TEORI}

\section{Promosi}

Promosi menurut Alma (2017:79) adalah suatu bentuk pemasaran yang merupakan aktifitas pemasaran yang berusaha menyebarkan informasi, mempengaruhi dan mengingatkan pasar sasaran atas perusahaan dan produknya agar bersedia menerima, membeli, dan loyal pada produk yang ditawarkan perusahaan yang bersangkutan. Armstrong dan Kotler dalam Teguh (2012:643) promosi yang sering digunakan dalam mengkomunikasikan produk adalah : Periklanan (Advertising), Penjualan Pribadi (Personal Selling), Pemasaran Langsung (Dirrect Selling), Promosi Penjualan (Sales Promotion), Hubungan Masyarakat dan Publisitas (Public Relation and Publicity).

\section{Kualitas Pelayanan}

Pelayanan adalah merupakan suatu proses, proses tersebut menghasilkan suatu produk yang berupa pelayanan, yang kemudian diberikan kepada pelanggan (Moenir, 2010:16). Kualitas apabila dikelola dengan tepat, berkontribusi positif terhadap terwujudnya kepuasan dan loyalitas pelanggan. Kualitas memberikan nilai plus berupa motivasi khusus bagi para pelanggan untuk menjalin ikatan relasi saling menguntungkan dalam jangka panjang dengan perusahaan.

Ada lima dimensi faktor utama dalam penentuan kualitas jasa pelayanan Tjiptono (2015:70) adalah:

1. Tampilan fisik atau Tangibles yaitu penampilan dan kemampuan langsung sarana dan prasarana fisik yang meliputi fasilitas fisik perlengkapan, karyawan dan sarana komunikasi.

2. Keandalan atau Reliability yaitu kemampuan perusahaan untuk memberikan pelayanan yang disajikan dengan segera, akurat dan terpercaya/memuaskan. 
3. Daya tanggap atau Responsiveness, yaitu keinginan para karyawan/staf untuk membantu para pelanggan dan memberikan pelayanan yang tanggap.

4. Jaminan atau Assurance yaitu meliputi pengetahuan, kompetensi, kesopanan dan sifat dapat dipercaya yang dimiliki para staf, bebas dari bahaya, resiko atau keragu-raguan.

5. Empati atau Emphaty yaitu memberikan perhatian yang bersifat individual atau pribadi secara tulus kepada pelanggan dan kemudahan dalam melakukan hubungan komunikasi serta berupaya untuk memahami keinginan dan kebutuhan pelanggan

\section{Keputusan Pembelian}

Menurut Kotler dan Armstrong (2017:227) mengemukakan bahwa "keputusan pembelian adalah tahap proses keputusan dimana konsumen secara aktual melakukan pembelian produk". Menurut Kotler (2016:202), keputusan pembelian yang dilakukan oleh konsumen dipengaruhi oleh empat faktor yaitu faktor budaya, faktor sosial, faktor pribadi, dan faktor psikologis.

\section{METODE PENELITIAN}

\section{Regresi Linear Berganda}

Metode yang digunakan adalah Regresi linear berganda, Koefisien Determinasi dan uji hipotesis dengan uji t dan uji F. Bentuk umum persamaan regresi berganda adalah sebagai berikut (Sugiyono, 2014:192):

$$
Y=a+B 1 X 1+B 2 X 2+B 3 X 3+e
$$

Dimana :

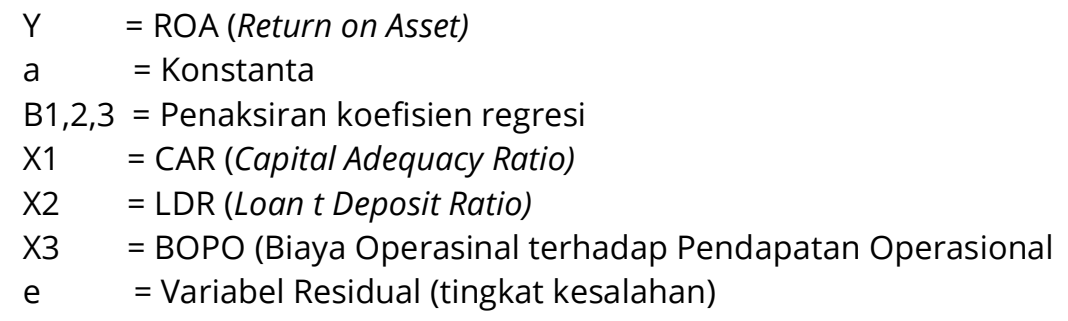

Koefisien Determinasi (R2)

Kekuatan pengaruh variabel bebas terhadap variasi variabel terikat dapat diketahui dari besarnya nilai koefisien determinasi (R2 ) yang berada antara nol dan satu. Nilai yang mendekati satu berarti variabel-variabel independen memberikan hampir semua inforrmasi yang dibutuhkan untuk memprediksi variasi variabel dependen (Ghozali, 2015:82). Interpretasi: Jika R2 mendekati 1 (semakin besar nilai R2 ), menunjukkan bahwa sumbangan atau kontribusi variabel bebas terhadap variabel terikat secara simultan semakin kuat.; dan Jika R2 mendekati 0 (semakin kecil nilai R2 ), menunjukkan bahwa sumbangan atau kontribusi variabel bebas terhadap variabel terikat secara simultan semakin lemah.

\section{HASIL DAN PEMBAHASAN}

Hasil dan Pembahasan

Analisis Regresi Berganda

Perhitungan statistik dalam analisis regresi berganda dijelaskan pada tabel berikut ini : 
Tabel 1. Hasil Analisis Regresi Linear Berganda Variabel Promosi $\left(\mathrm{X}_{1}\right)$, Kualitas Pelayanan $\left(\mathrm{X}_{2}\right)$ terhadap Keputusan Pembelian (Y).

Coefficients $^{a}$

\begin{tabular}{|c|c|c|c|c|c|}
\hline \multirow{2}{*}{ Model } & \multicolumn{2}{|c|}{$\begin{array}{l}\text { Unstandardized } \\
\text { Coefficients }\end{array}$} & \multirow{2}{*}{$\begin{array}{c}\text { Standardized } \\
\text { Coefficients } \\
\text { Beta }\end{array}$} & \multirow[t]{2}{*}{$\mathrm{t}$} & \multirow{2}{*}{ Sig. } \\
\hline & B & Std. Error & & & \\
\hline $\begin{array}{ll}1 & \text { (Constant) } \\
& \text { X1 } \\
& \text { X2 }\end{array}$ & $\begin{array}{l}.203 \\
.264 \\
.531\end{array}$ & $\begin{array}{l}.879 \\
.129 \\
.131\end{array}$ & $\begin{array}{l}.333 \\
.659\end{array}$ & $\begin{array}{l}.231 \\
2.048 \\
4.054\end{array}$ & $\begin{array}{l}.818 \\
.046 \\
.000\end{array}$ \\
\hline
\end{tabular}

a. Dependent Variable: $Y$

Berdasarkan tabel diatas maka nilai yang diperoleh dapat diformulasikan kedalam persamaan regresi linear berganda berikut ini :

$$
Y=0,203+0,264 X_{1}+0,531 X_{2}+e
$$

Persamaan regresi linear tersebut dapat dijelaskan bahwa :

a. Nilai konstanta 0,203 mempunyai arti bahwa apabila variabel promosi $\left(X_{1}\right)$ dan kualitas pelayanan $\left(\mathrm{X}_{2}\right)$ dianggap sama dengan nol (0) maka variabel keputusan pembelian polis asuransi (Y) pada PT. Tugu Kresna Pratama Kota Bengkulu akan tetap sebesar 0,203.

b. Variabel Promosi $\left(X_{1}\right)$ mempunyai nilai koefisien regresi sebesar 0,264 yang berarti bahwa promosi mempunyai pengaruh positif terhadap keputusan pembelian polis asuransi pada PT. Tugu Kresna Pratama Kota Bengkulu (Y). Semakin tinggi/kuat promosi yang yang dilaksanakan pada pada PT. Tugu Kresna Pratama Kota Bengkulu maka akan meningkatkan keputusan pembelian polis asuransi pada PT. Tugu Kresna Pratama Kota Bengkulu

c. Variabel kualitas pelayanan $\left(\mathrm{X}_{2}\right)$ mempunyai nilai koefisien regresi sebesar 0,531 yang berarti bahwa kualitas pelayanan mempunyai pengaruh positif terhadap keputusan pembelian polis asuransi pada PT. Tugu Kresna Pratama Kota Bengkulu (Y), yaitu semakin tinggi/kuat kualitas pelayanan pada PT. Tugu Kresna Pratama Kota Bengkulu maka akan meningkatkan keputusan pembelian polis asuransi pada PT. Tugu Kresna Pratama Kota Bengkulu.

Koefisien Determinasi (R Square) digunakan untuk Koefisien determinasi ini digunakan untuk mengetahui seberapa besar pengaruh variabel-variabel bebas terhadap variabel terikatnya. Secara Sederhana koefisien determinasi dihitung dengan mengkuadratkan koefisien korelasi (R).

Tabel 2. Hasil Koefisien Determinasi ( $R$ Square)

Model Summary

\begin{tabular}{|c|l|l|l|l|}
\hline \multicolumn{1}{|c|}{ Model } & \multicolumn{1}{|c|}{$\mathrm{R}$} & \multicolumn{1}{c|}{ R Square } & Adjusted R Square & Std. Error of the Estimate \\
\hline 1 & $.990^{\mathrm{a}}$ & .980 & .979 & .761 \\
\hline
\end{tabular}

a. Predictors: (Constant), X1, X2

Nilai $R^{2}$ atau $R$ Square dapat dibuat pada tabel model summary. Hasil pengolahan data menunjukkan bahwa nilai $\mathrm{R}^{2}$ sebesar 0,980 . Nilai tersebut menggambarkan bahwa sumbangan variabel independen yaitu promosi $\left(\mathrm{X}_{1}\right)$, kualitas pelayanan $\left(\mathrm{X}_{2}\right)$ terhadap naik turunnya atau variasi variabel dependen yaitu keputusan pembelian polis asuransi pada PT. Tugu Kresna Pratama Kota Bengkulu (Y) adalah sebesar $98 \%$ dan sisanya 2\% merupakan sumbangan/kontribusi dari variabel lain yang tidak diteliti dalam penelitian ini. Uji hipotesis simultan (uji F) digunakan untuk mengetahui pengaruh dari variabel independen secara bersama-sama/keseluruhan terhadap variabel dependen. Uji ini dapat dilakukan dengan melihat nilai signifikasi (Sig.) pada tabel Anova apabila signifikansinya < 0,05 (5\%) maka Ho ditolak dan Ha diterima artinya dapat dikatakan bahwa hipotesis penelitian diterima. 
Tabel 3. Hasil Uji Simultan (Uji F)

ANOVA $^{a}$

\begin{tabular}{|c|c|c|c|c|c|}
\hline Model & $\begin{array}{l}\text { Sum of } \\
\text { Squares }\end{array}$ & Df & $\begin{array}{l}\text { Mean } \\
\text { Square }\end{array}$ & $F$ & Sig \\
\hline $\begin{array}{ll}1 & \text { Regression } \\
& \text { Residual } \\
\text { Total }\end{array}$ & $\begin{array}{l}1495.084 \\
30.116 \\
1525.200\end{array}$ & $\begin{array}{l}2 \\
52 \\
54\end{array}$ & $\begin{array}{l}747.542 \\
.579\end{array}$ & 1290.733 & $.000^{\mathrm{b}}$ \\
\hline
\end{tabular}

a. Dependent Variable: $Y$

b. Predictors: (Constant), X2, X1

Dari tabel di atas diketahui bahwa nilai signifikannya adalah $<0,05$ yaitu 0,000 artinya secara simultan atau bersama-sama variabel promosi $\left(X_{1}\right)$ dan kualitas pelayanan $\left(X_{2}\right)$ berpengaruh signifikan terhadap keputusan pembelian polis asuransi pada PT. Tugu Kresna Pratama Kota Bengkulu.

Uji hipotesis secara parsial digunakan untuk mengetahui pengaruh dari masing-masing variabel independen terhadap variabel dependen. Uji ini dilakukan dengan melihat nilai signifikasi (sig.) apabila signifikansinya < 0,05 (5\%) maka Ho ditolak dan Ha diterima artinya dapat dikatakan bahwa hipotesis penelitian diterima sebagaimana dapat dilihat pada tabel koefisien berikut ini :

Tabel 4. Hasil Uji Parsial (Uji t)

Coefficients $^{\mathrm{a}}$

\begin{tabular}{|ll|l|l|l|l|l|}
\hline \multirow{2}{*}{ Model } & \multicolumn{2}{|c|}{$\begin{array}{c}\text { Unstandardized } \\
\text { Coefficients }\end{array}$} & \multicolumn{2}{c|}{$\begin{array}{c}\text { Standardized } \\
\text { Coefficients }\end{array}$} & t & Sig. \\
\cline { 3 - 6 } & \multicolumn{2}{|c|}{ B } & Std. Error & Beta & & \\
\hline 1 & (Constant) & .203 & .879 & & .231 & .818 \\
& X1 & .264 & .129 & .333 & 2.048 & .046 \\
X2 & .531 & .131 & .659 & 4.054 & .000 \\
\hline
\end{tabular}

a. Dependent Variable: $Y$

Dari tabel di atas dapat diketahui bahwa :

a. Variabel promosi $\left(X_{1}\right)$ memiliki nilai signifikansi $<0,05(5 \%)$ yaitu sebesar 0,046 sehingga dapat disimpulkan bahwa promosi $\left(X_{1}\right)$ secara parsial memiliki pengaruh yang signifikan terhadap keputusan pembelian polis asuransi pada PT. Tugu Kresna Pratama Kota Bengkulu.

b. Variabel kualitas pelayanan $\left(X_{2}\right)$ memiliki nilai signifikansi $<0,05(5 \%)$ yaitu sebesar 0,000 sehingga dapat disimpulkan bahwa kualitas pelayanan $\left(\mathrm{X}_{2}\right)$ secara parsial memiliki pengaruh yang signifikan terhadap keputusan pembelian polis asuransi pada PT. Tugu Kresna Pratama Kota Bengkulu.

\section{KESIMPULAN DAN SARAN}

Kesimpulan

1. Promosi (X1) secara parsial berpengaruh signifikan terhadap keputusan pembelian polis asuransi pada pada PT. Tugu Kresna Pratama Kota Bengkulu (Y) karena nilai signifikannya $0,046<0,05$.

2. Kualitas pelayanan (X2) secara parsial berpengaruh signifikan terhadap keputusan pembelian polis asuransi pada pada PT. Tugu Kresna Pratama Kota Bengkulu (Y) karena nilai signifikannya $0,000<0,05$.

3. Variabel promosi (X1), kualitas pelayanan (X2) secara simultan atau bersama-sama berpengaruh signifikan terhadap keputusan pembelian polis asuransi pada pada PT. Tugu Kresna Pratama Kota Bengkulu karena nilai signifikannya 0,000 <0,05. 
p-ISSN 2798-0499 e-ISSN 2798-0502

Saran

Dalam penelitian ini penulis menyarankan menyarankan kepada pihak PT. Tugu Kresna Pratama Bengkulu agar lebih diperhatikan dan ditingkatkan lagi semua indikator promosi dan dimensi kualitas pelayanan supaya ditanggapi dengan baik atau minimal nasabah puas dengan pelayanan yang diberikan serta nasabah tertarik dengan komunikasi melalui promosi sehingga kepercayaan nasabah maupun calon nasabah meningkatkan untuk memutuskan pembelian polis asuransi pada PT. Tugu Kresna Pratama Bengkulu dibandingkan perusahaan asuransi lainnya.

\section{DAFTAR PUSTAKA}

Adiputra, Yustinus Riyan dan Khasanah, Imroatul. 2016. Jurusan Manajemen Fakultas Ekonomika dan Bisnis Universitas Diponegoro Semarang. Pengaruh Kualitas Produk, Kualitas Pelayanan, Citra merek dan Persepsi Harga terhadap Keputusan Pembelian Jasa Asuransi Jiwa (Studi pada AJB Bumiputera 1912 Cabang Cibinong. Diponegoro Journal of Management http://ejounalsl.undip.ac.id/index.php/dbr Volume 5 Nomor 2 Tahun 2016, Halaman 1-16 ISSN (online) : 2337-3792.

Alma, Buchari. 2017. Manajemen Pemasaran dan Pemasaran Jasa. Bandung : Alfabeta

Irawan, J., \& Susena, K. C. (2020). The Relationship Of Product Completeness And Price With Purchase Decision On Manna's New Hope Shop South Bengkulu. JURNAL EMAK, 1(3), 91-99.

Kotler, Philip . 2016. Manajemen Pemasaran. Jakarta : PT Indeks

Kotler, Phillip dan Garry Amstrong. 2017. Dasar-Dasar Pemasaran. Alih Teguh. Jakarta : Prenhalindo

Moenir, H.A.S. 2010. Manajemen Pelayanan Umum di Indonesia. Jakarta : Bumi Aksara.

Ratminto dan Atik Septi Winarsih. 2012. Manajemen Pelayanan. Yogyakarta : Pustaka Pelajar

Setyawan, Riza. 2013. Pengaruh Promosi, Fasilitas Dan Kualitas Layanan Terhadap Keputusan

Pembelian Polis Asuransi Jiwa (Studi pada PT Asuransi Jiwa Sinarmas (MSIG Life) Cabang Madiun. Skripsi Program Studi Manajemen Fakultas Ekonomi Universitas Muhammadiyah Ponorogo.

Sugiarto. 2017. Psikologi Pelayanan dalam Industri Jasa. Jakarta : Gramedia Pustaka

Sugiyono, 2014. Metode Penelitian Kuantitatif Kualitatif. Bandung : Alfabeta

Swastha, Basu. 2015. Azas-Azas Marketing. Yogyakarta: Liberty

Teguh, Hendra dan A Rusly, Ronny, 2012. Manajemen Pemasaran. Jakarta : PT Prenhallindo

Tjiptono, Fandy. 2015. Manajemen Pemasaran Jasa. Malang : Bayumedia Publishing 